\title{
Some Aspects of the Islamic Contribution to Scientific Culture
}

Maurice Bucaille, M.D.

Paris, France

DOI: http://dx.doi.org/10.5915/21-1-5518

In the treatise "Histoire Generale des Civilisations" (General History of Civilizations) by Professor Maurice published in 1955, the Islamic civilization is appraised as follows: "At the time of the decline of civilisation in Western Europe and after the damages caused by the nomads in the Asiatic world, the blossoming of Islam is an outstanding event." To a great extent and over many centuries, the Islamic world became an educator in the West and in the East, after the recollecting of a considerable number of ancient written works.

The authors of this treatise are full of admiration for the human enterprises related to this blossoming. They note that before Saint Thomas went to Italy, Ibn Sinā was born in Turkestan; the mosques of Damascus and Cordoba were erected before the Catheral of Notre Dame in Paris. Nevertheless, they do not direct the attention of the readers to the causes of these events, particularly the influence of purely religious factors. In fact, the relationship between cultural development and the teachings of the new religion is not emphasized as should logically have been done.

In order to clearly understand what happened, one must remember that when Islam appeared, the culture in the Western countries was exclusively oriented, under Christian influences, toward the permanent reference to the writings of the old times. Such a way of thinking may be highly advantageous from a certain point of view, but it is rather inefficient to promote progress.

To innovate was the work of Islam: this aim clearly appears when the Qur'ānic text is carefully studied. Islam promoted a new mentality by prescribing to man - for the first time in the spiritual history of mankind - to ponder over the phenomena of nature which are accessible to his observation, and to study them in order to discover the signs of the Divine omnipotence. This essential aspect leads us to put for-

Ancien Ches de Clinique Chirurgicale a la Faculte, Paris, France.

Reprint reques/s: Docteur Maurice Bucaille, 114 Avenue de Versailles, 75016, Paris, France.

This speech was delivered at the 20th Annual Convention of IMA, Houston, TX, November, 1987. ward peculiar statements in the Qur'ān about extremely diversified matters.

These numerous teachings concerning material objects are accompanied by considerations related to their degree of evidence for a human being observing them. When the phenomenon is easily understandable, the Qur'ān only recommends "to hear" the statement and "to ponder over" it. When more complex matters are concerned, the Qur'ān insists upon the necessity of "reasoning" about them, while emphasizing the necessary condition to be "endowed with intellect" and "sagacious" for this purpose. Moreover, there are phenomena which may be approached by human observation and whose importance, as signs of Divine omnipotence, can only be evaluated by "people possessing science." At the top of these statements, many of them concern matters which only modern science is only able to make the precise meaning understandable.

Here I shall make a general survey of these numerous topics.

Very often, the Qur'ān states "Have you not seen that," as a call to man inviting him to observe.

If this statemnt concerns a commonplace matter, the Qur'an simply invites man "to hear" it, in order to uderstand. Thus, we read in the Qur'ān:

"Allāh sent water down from the sky and thereby $\mathrm{He}$ revived the ground after its death. Verily in that there are signs for people who hear."'

In the same surrah, the verses 68 and 69 contain a call to reflection about bees and honey; the verses deduce:

"Verily in that there is a sign for people who are pondering over it."'

Many statements of this kind are scattered in the Qur'ān. Consequently one must have a good memory for them:

"Verily in that there are signs for people who remember rightly."

At a higher degree, a call to reason completes the previous recommendations, for example concerning the fruits of the vine and the palm trees or the 
celestial bodies submitted to the orders of God. ${ }^{\circ}$ About this call to reason, Allāh says:

"In the creation of the Heavens and the Earth, in the disparity of night and day, in the ships which run upon the sea for the profit of mankind, in the water which Allah sent down from the sky, thereby reviving the Earth after its death, in the beasts of all kinds $\mathrm{He}$ scattered therein, in the change of the winds and the subjected clouds between the sky and earth, there are signs for people who reason."

These statements about observable date are intended for the refletion of people who are "endowed with intellect," those who are "sagacious.".

\section{Alāh says:}

"Behold in the creation of the Heaven, and the Earth and the alternation of night and day there are indeed signs for those endowed with intellect."

\section{Allāh also says:}

"See you not that Allāh sends down rain from the sky and leads it through springs in the earth? Then He causes to grow therewith, produce of various colors then it withers. You will see it grow yellow then He makes it dry up and crumble away. Truly in this is a message of remembrance to those endowed with intellect."

\section{Allāh also says:}

"He who has made for you the Earth like a carpet spread out, has enabled you to go about therein by roads and channels and has sent down water from the sky. With it have We produced diverse pairs of plants each separate from the others. Eat for yourselves and pasture your cattle. Verily in this are signs for those who are sagacious." "10

These intellectual capabilities however are not sufficient, since the Qur'ān emphasizes the need for man to possess the proper knowledge, therefore an implication of seeking for science. Allāh says:

"Allah explains the signs in detail for people who know." "1

The statement is similarly repeated in another verse:

"We have detailed the signs for people who know" "12

The teachings which are beneficial to those who possess science are explained for the men of all times, since the Qur'ān contains many statements about natural phenomena whose precise meanings could not be understood except in modern times due to scientific progress. Examples of them were given in my book, "The Bible, the Qur'an and Science." "I should like here to only mention the multiplicity of statements concerning human reproduction and some data concerning physiology. In 1976, I delivered a lecture about them at the French Academy of Medicine in Paris. The assembly was agreeing about their close conformity with the modern discoveries. But these notions were absolutely unknown in the time of the Prophet Muhammad. Consequently their communication during the 7 th century of the Christian era cannot receive a human explanation. This is demonstrated by what we know about the history of sciences. Moreover, the Qur'ān lets us know very interesting details regarding this point. After hearing these verses, people around the Prophet were, of course, inclined to put questions concerning the possible secular knowledge of the Prophet and to tell him: "You have studied." Alläh says:

"So, We display the signs that they say: You have studied...".".4

The end of the verse is highly significant, for immediately Allāh corrects this hypothesis, by saying that the clear explanation is given to people who know:

"... So that, We are clearly explaining it to people who know." "s

Concerning this point, we must remember that the Prophet Muhammad was "illiterate."

Allah says:

"Those who follow the Apostle, the unlettered Prophet..."s"16

"... So believe in Allāh and His Apostle the unlettered Prophet..." "1

He would not have been in a position to scientifically study the matters which are concrned here and to possess a true knowledge about them, the more so since their knowledge would have absolutely exceeded what was known in his time.

By this way, many Qur'ānic teachings have established the part given to science in the act of searching for signs of the Divine omnipotence through human investigations.

When we have before our eyes all these evidences which are written in the Qur'ān, it is dismaying that modern authors, in their explanation of the blossoming of the scientific culture in Islam, pass over them in silence. Before the Qur'anic revalation there was no Holy Scripture ordering man to seek for science. 
To seek for science is the mark of the new mentality introduced by Islam.

When one assents to recognize the existence in the Qur'an of these verses containing calls to the search of science, one may easily imagine that, at the time of the Qur'anic Revelation and later on, at the time of the expansion of Islam, such teachings invited men to ponder over the topics they evoked. How could a believer in Allāh fail to want to increase his knowledge in the fields where $\mathrm{He}$ found arguments in favor of the Omnipotence of the the Creator.

The meaning of these appeals for an increase of secular knowledge was first grasped by the Prophet. We should remember his "'Ahādith" evoking science.

\section{"Seek for science, even in China."}

In order to avoid a misunderstanding concerning the meaning of science/knowledge, here like in the Qur'an, I should like to stress that the knowledge which is concerned is only the secular one. How could one imagine that, in the time of the Prophet, one might conceive of the possibility to seek for religious science by going to China. I must make it clear, since there are authors who refuse to give to the word science/knowledge, another meaning than a religious one, despite the fact that the statements quoted here are exclusively related to physical phenomena.

Another Hadith is even more explicit, since the Prophet Muhammad states that:

"The scientists' ink is more precious than the martyrs' blood."

Two values are confronted here: the sacrifice of the life with the aim of propagating the Faith and the ability of the scientists to persuade people through their writings. Is it not the praise of the Faith through the reason, in the light of science?

I cannot detail here what Islam brought to scientific culture in many disciplines which were greatly enriched by its contribution. My intent is only to illustrate by significant examples the fact that a new way of thinking and a great open-mindedness exerted a considerable influence upon the researchers, as well as upon the enrichment of knowledge and the usefulness for mankind.

In the Muslim world, the first educational establishments were originally founded around mosques. Soon after, universities began to appear, long before the institution in the West of similar establishments. These universities became famous far

Editor's Note: These 2 'A hadith are not reported in the six major 'A hädith books. from the borders of the countries where they had been set up. At that time in Europe, to go and study in Muslim universities in Spain, particularly in Cordoba, was a common practice. In these places students and visitors could exchange ideas, and when they returned to their respective countries, the benefit was great for literature, arts and sciences, and among them medicine.

Why did this attraction over several centuries induce those who wanted to learn to go to these places where the search of knowledge was satisfied?

At first - but not only - with a view to the discovery of many works of antiquity, since to be acquainted with them is always beneficial. Here is a significant example. At Baghdad, in 830 , Caliph alMa'mūn founded the institution called " $B \overline{\overline{i t}}$ alHikmah"; at Cordoba, later on, a similar establishment afforded a lot of possibilities in this field. Two Caliphs in Baghdad gave the evidences of their major interest for the intellectual riches, preferable to the customary spoils of war. Hārūn al-Rashid, victorious in Turkey, only required the delivery of writings of Antiquity, an exigency which is not usual in such a circumstance. Al-Ma'mūn made a similar choice when he had defeated the Byzantine Emperor Michael the Third. During the 8th and 9th centuries, Yühanna ibn Māsāwih and Hauayn ibn 'Ishaq, in Baghdad, directed the translation of a great number of ancient works, and the knowledge of these translations was made easier when paper could be manufactured there, at the same epoch. In the libraries of the Muslim universities there were extraordinary collections of ancient works, like in the famous library of al-Hakim in Cordoba.

It would be erroneous, however, to suppose that the Islamic contribution was limited to the transfer of ancient works after their translation. There is unfortunately in the West a great tendency to propagate such wrong opinions. I remember to have heard, not long ago, a very eminent medical practitioner, speaking at a meeting at UNESCO, exposing a survey of medicine through the ages. He formally declared that, from the Greek Antiquity until the 19th century in Europe, absolutely nothing was to be noticed: he had passed over in silence many improvements and innovations which must be evoked here.

In fact, in medicine like in other disciplines, innovations were introduced and taught during centuries, from Samarkand in Central Asia to the Spanish universities, particularly in Cordoba, in very renowned places like Baghdad, Cairo, Tunis, Qayrawān, Fez, ...etc.

Sometimes the notoriety is so great that a discovery is erroneously attributed. Such is the case of what we call "Arabic numerals." Their origin is Indian in fact. They were introduced in Baghdad by alKhawārizmi who understood, in about 830 , their considerable interest related to the decimal system 
and he introduced the use of the figure zero. With the use of the Roman numerals, to calculate was highly complicated; with the so called Arabic numerals, it was considerably simplified. Al-Khawārizmi was the pioneer of algebra: algebra is an Arabic word. In multiple fields of mathematics, the application of new methods brought enormous progress. I can only quote the names of several mathematicians in those times who were particularly famous:

Thäbit ibn Qurrah during the 15th century, al-Țūi during the 10th century, al-Kashi during the 15 th century in arithmetic, 'Umar al-Khayyām during the 11 th century for algebra and geometry, and the three brothers 'Abū Mūsā for trigonometry in the 9th century. I must make a special mention for what was done concerning the infinitesimal calculus and many other branches in mathematics.

Physics received great benefits from major improvements in mathematics. Optics cannot be evoked without quoting al-Häzin who died during the 10th century, and Kamäl al-Din Färisí who lived in the 14th century: the latter gave a mathematical and experimental explanation of the reflection and refraction of light. One must also mention discoveries and new technics in mechanics to which the three brothers Mūsā gave their contribution, and after them alKhawārizmi and al-Djazari. I have_quoted many names but $\mathrm{I}$ have not mentioned al-Birüni. and a lot of discoveries that I cannot detail here. Moreover emphasis is to be laid on the plurality of disciplines in which many of these scientists became famous: a common contingency in those times.

Let us come to Astronomy. In the Qur'ān statements concerning Astronomy are numerous and associated with invitations to study them; thus one cannot be surprised by the importance given to the study of Heaven in the scientific research in these times. In 707 the Ommiad Caliph 'Abd al-Malik founded an observatory in Damascus, and about 50 years later, during the reign of al-Mansūr, an astronomical school was opened in Baghdad. In this discipline, during the 9 th century al-Battani $\overline{\text { acquired }}$ a great renown, as well as the astronomers during the reign of al-Ma'mūn. To this school must be credited the new evaluations of the eclipse, the measure of the precession of equinoxes and the measure of the meridian. During the 13th century the equipment of the Maräghah observatory, in the Mogolian capital of Hulāqu, directed by Nassir-il-Dīn al-Tüsi, was the best in the world, so much so that the King Alphonso the Tenth of Castile ordered to build a similar one in Burgas. This open-minded monarch commanded the publication of new astronomical tables which were called "Tables of Alphonso" despite the fact that they were much inspired by astronomers from other countries. The contribution of these astronomers (among them al-Birūni) to the corrections of the Ptolemaic system was a prelude to the changes in- troduced by Copernicus at the beginning of the 16th century.

In close relationship with astronomy, considerable progress was accomplished in the field of geography, particularly concerning cartography, with view of a better evaluation of latitudes and longitudes, on the occasion of journey undertaken in a spirit of discovery of unknown territories. One of the most successful outcomes belongs to 'Idrísi. At the beginn-

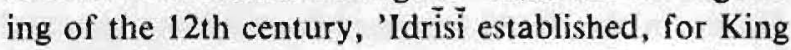
Roger of Sicily, the famous "Book of Roger", the best work of cartography in this time, remained the best one during more than three centuries.

The expansion in the field of medicine has its starting point in Baghdad at the beginning of the 8th century. After a while we shall mention the rulers who delegated the initial responsibilities and the practioners to whom they were delegated: the latter were two Christians, the fact remaining nonetheless that the intellectual driving force behind this lies in the Qur'ānic teachings concerning the relations between God, nature and mankind. All these teachings led those, who were "sagacious" and "endowed with intelligence" and able "to ponder over" them (according to what the Qur'ann said), to investigate the human body; moreover emphasis is laid in the Qur'ān on the fact that God, has said

"We fashioned man according to the best organisational plan", " (making him out of components "with" harmony).

I have commented on all these Qur'ānic expressions and many others about the same topic in my book "What is the Origin of Man? The answers of science and the Holy Scriptures".'19

As to the state of illness, which was considered in ancient times as being the result of purely supernatural factors, a new spirit putting forward the research of causes rose in the minds. Indeed, a rational explanation had begun to appear with Hippocrates during the 4 th century before Christ and later on with Galen during the second century of the Christian era. Unfortunately at the beginning of Islam, directives like what Galen suggested in favor of a materialistic understanding of phenomena, had been somewhat forgotten by those who were in charge of patients. The prescriptions of Islam concerning the search of science brought a major contribution to the research of the causes in medicine and the use of remedies according to essentially rational bases.

Very likely al-Rāzi was the most famous practitioner in his time and his authority remained high during more than a half-millennium after the 9 th century. His encyclopaedia, known as "Continens" in the West, was at the origin of an impressive progress in comparison with what preceded it. Today the students of the Faculty of Medicine located at Rue 
des Saints Peres in Paris go past his statue and the statue of Avicenna (Ibn Sina); this is to express our indebtedness for their contributions and to make it known. From the death of Avicenna, in the first part of the 11th century to the Renaissance and later on, his "al-Qānūn fï-al-Tibb" or "Precepts of Medicine" remained a basic treatise for its general considerations and special details concerning many diseases. About at the same epoch, Ibn Haytham (Al Hazen in the West) was a pioneer of experimental teachings and a famous ophthalmologist, while alMaswili was able to treat cataract. At the same time 'Abü-l-Qäsim al-Zahrawi (Albucassis in the West) introduced the arterial ligature in surgery, more than 5 centuries before Ambroise Pare. To this major progress in surgery, we must add the production of various surgical instruments according to apropriate patterns. Mention is also to be made of Isaac the Hebrew from Qayrawān, specialist in ophthalmology, and of al-Biruni and al-Bitar who discovered many new medicines. Cordoba was a particular renowed center for medicine: Avenzoar (ibn Zuhr), Averroes (ibn Rushd), Maimonides (Mūsā ibn Maymūn), and 'Abu-l-Qāsim al-Zahräwi gave their contribution to its fame.

In closing the matter concerning medicine, I should like to report an anecdote which consoles a bit for having often heard or read preconceived judgments about this topic. The anecdote took place in 1976 when I had delivered a lecture before the French Academy of Medicine in Paris concerning statements in the Qur'an which are of interest to physicians. I remember that after the lecture, I had a long talk with one of its members who was known as a practicing Christian. He asked me to tell him more about the Qur'an, about what we call "Arabic Medicine" and the memorable discoveries made in Muslim universities during this glorious period. He was full of admiration for Ibn al-Nafis, when I told him that, centuries before it was rediscovered in the West, the circulation of the blood from the heart to the lungs and back again was described by this physician in the 13th century. His admiration increased when I presented feats of this kind in medicine as a result of a new attitude on mind closely related to the Qur'anic teachings. Then he said to me by way of conclusion: "I wonder if a defeat of Charles Martel in Paitiers would not have been an advantage." Without doubt, this prominent doctor wanted to mean that there might have been an advantage for our culture in the West, if Islamic civilization had had an even greater influence. A breath of ecumenism had entered his spirit.

I have reasons to think that the rulers in Baghdad, as soon as Härün al-Rashīd became Caliph, had a similar feeling when they had to make a decision concerning public health and teaching of medicine in their capital. Hārūn al-Rashid appointed a Christian physician native of Khuzistan, Gabriel Ibn Bakhtichu, as director of the newly founded hospital. The same Caliph appointed another Christian physician, Yūhanna ibn Másāwih as successor of the former. He put him in charge of the translation of many ancient written works in the field of Medicine, giving him all the necessary means for this purpose. Yühanna ibn Māsāwīh lived a long time, since he taught medicine under the reigns of six successive Caliphs, the last one being al-Mutawakkil, in the middle of the 9th century. The teachings of Yühanna ibn Māsäwih had considerable repercussions, not only in the Muslim world but even far away from the banks of the Tigris and for a long time in the West. Many editions of the written works of Yuhanna ibn Masawih were published throughout numerous countries until 1605 in Lyons in France; moreover, a modern edition appeared in 1980 in Paris. There were many reasons for this, among them the very great importance given by Yühanna ibn Mäsāwih to the psycho-somatic aspects of diseases, whose role today is acknowledged as being significant. Also significant is the fact tht the Muslim rulers in Baghdad called on the skills they had thought to be the best ones, without any consideration of religious beliefs. His status remained unchanged during almost 70 years.

The Qur'ānic teachings enjoining a remarkable open-mindedness resulted in a mentality which was quite different from the attitude of mind in the West. when science began to spread ideas which were not in close conformity with the tradition. In such circumstances in the Muslim world, there was no suspicion and no quarrel like in the West in the Middle Ages and still recently in modern times; no hindrance to the search of science, no trial like the trial of Galileo or other ones against researchers who were sentenced to be burnt at the stake. Such abuses of power are today regretted by the highest authorities of the various Christian denominations, particularly the Roman Catholic Church. In the Islamic world there were several skirmishes without major consequences, but no deliberate hostility against science.

Religion and science are generally considered in Islam to be twin sisters, since the revealed word of God as well as the Prophet's tradition order every Muslim to seek for science. The achievements of Islamic civilization are explained by the observance of prescriptions dictated from the beginning of Islam: the outcome was the blossoming of the scientific culture.

Almost 14 centuries after the Qur'anic Revelation, one must be delighted to note that an official statement of the Catholic Church expresses the same confidence in the twinning of the respective values of Faith and Science. The Second Vatican Council made it clear in its "Message to the thinkers and scientists".

I am convinced that I could not find a more proper conclusion of this report than to quote one of its 
statements which seems to me to be of the utmost importance, since after a long conflict between Faith and Science, the highest authorities of the Catholic Church have proclaimed what follows:

"Today, as never before perhaps, thanks to God, there is a clear possibility of profound agreement between true Science and true Faith, both of which are servants of the one and only truth."

\section{References:}

1. Histoire Generale des Civilisations (General History of Civilisation). Editor, Gouzet, M Presses Universitaires de France, 1955.

2. Glorious Qur'ān, Chapter 16, vetse 65.

3. Glorious Qur'ān, Chapter 16, verses 68, 69.

4. Glorious Qur'ân, Chapter 16, verse 13

5. Glorious Qur'ān, Chapter 16, verse 67

6. Glorious Qur'ān, Chapter 16, verse 12
7. Glorious Qur'ān, Chapter 2, verse 164

8. Glorious Qur'ān, Chapter 3, verse 190

9. Glorious Qur'ān, Chapter 39, verse 21

10. Glorious Qur'ān, Chapter 20, versees 53, 54

11. Glorious Qur'ân, Chapter 10, verse 5

12. Glorious Qur'àn, Chapter 6, verse 97

13. Bucaille, M: The Bible, the Qur'an, and Science. The Holy Scriptures examined in the light of modern knowledge. 4th Edition. Publisher Seghers, Paris, France 1986.

14. Glorious Qur'ān Chapter 6, verse 105

15. Glorious Qur'ān, Chapter 6, verse 105

16. Glorious Qur'ān, Chapter 7, verse 157

17. Glorious Qur'ān, Chapter 7, verse 158

18. Glorious Qur'ān, Chapter 95, verse 4

19. Bucaille, M: What is the origin of man. The answers of science and the Holy Scriptures. 3rd Edition. Publisher Seghers, Paris, France 1985. 